\title{
チェロ運弓動作の計測と習熟過程の解析
}

○荻原直道，佐々木宣明，山崎信寿（慶大・理工）

\section{Motion Measurement of Violoncello Bowing and Analysis of Skill-Acquisition}

Naomichi Ogihara, Nobuaki Sasaki, Nobutoshi Yamazaki(Fac. of Sci. \& Tech., Keio University)

\section{1.はじめに}

弦楽器の演奏など，身体と操作対象との物 理的相互作用がある動作の遂行には, 運動

(位置, 速度) と力の同時制御という高度な

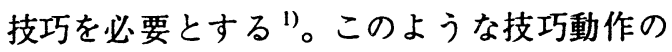
獲得過程を調べることで，ヒトの身体構造の 特徵である冗長な自由度の最適化メカニズム か明らかになれば，技能修得の効率化なと様々 な応用が期待できる。本研究では, 非日常的 動作で, 被験者の生活履歴の影響が少ないと 考えられるチェロの運弓動作を例として動作 計測を行い，その習熟過程の解析を試みた。

\section{2. 方法}

\section{2-1.計測システム}

計測システムを図 1 に示す。本研究では, チェロの音色を決める弓圧, 弓速, サウンディ ングポイントを計測し，それらの情報をリア ルタイムで視覚的にフィードバックすること ができる計測用模擬チェロを製作した。これ
は複雑で評価が困難な音の要素を, 単純な力 学量に置き換えることによって簡略化し，ヒ トと楽器系の相互作用の包括的な解析を可能 にする意義を持つ。弓圧は弦に相当する回転 円筒の両端に取り付けられたひずみゲージ式 片持ちはりセンサで求め, 弓速は円筒の回転 をポテンショメータで計測し，これを時間微 分することにより求めた。弦に対する弓の接 触位置であるサウンディングポイントは弦の 左右にかかる力の比より算出した。得られた データは図1のようにリアルタイムで画面に 表示することで被験者にフィードバックした。 弓の毛の部分はゴムとした。

上肢, 体幹, 弓, チェロ本体の 3 次元運動 の計測には, 赤外線半導体カメラシステム （浜松ホトニクスC3570）を用いた。各体節 にはそれぞれ 3 点の標点を装着し, 回旋角度 を含む各節の関節角度を計測した。関節角度 は 3 軸系オイラー角により定義した。

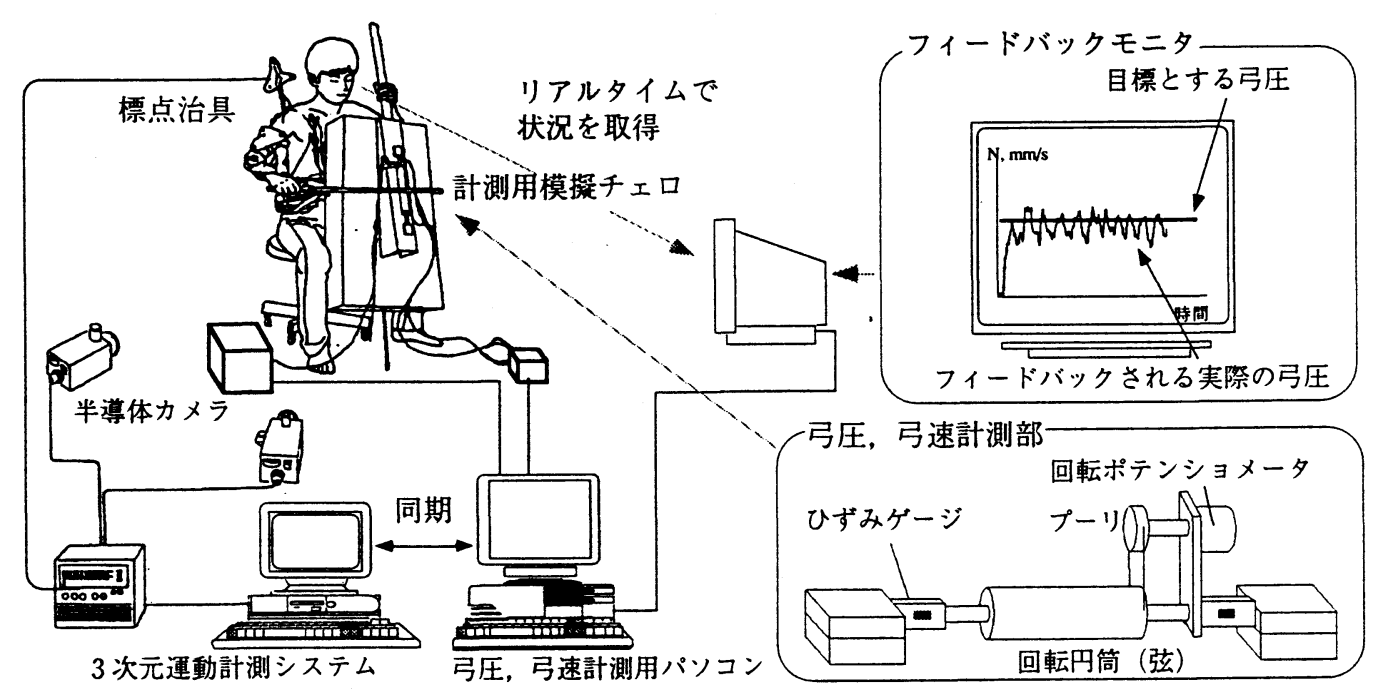

図1計測システム 

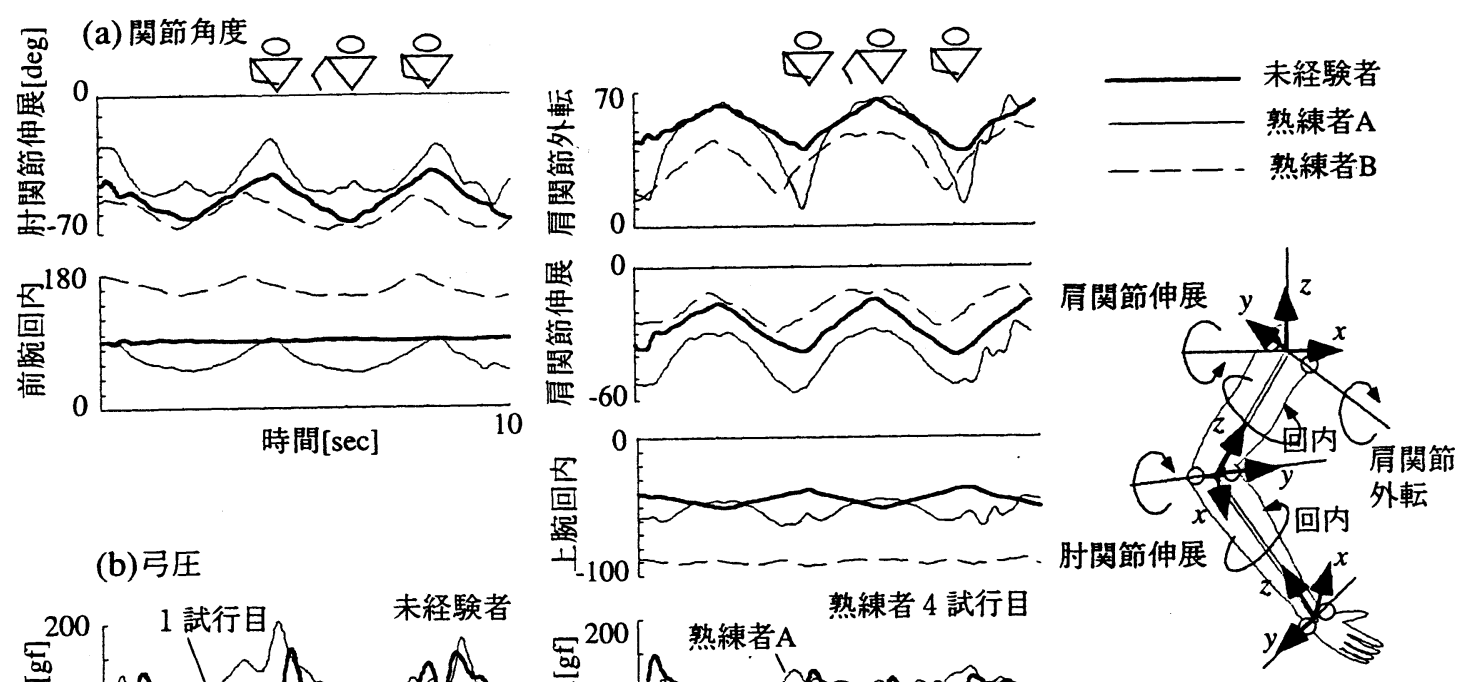

(b)弓圧
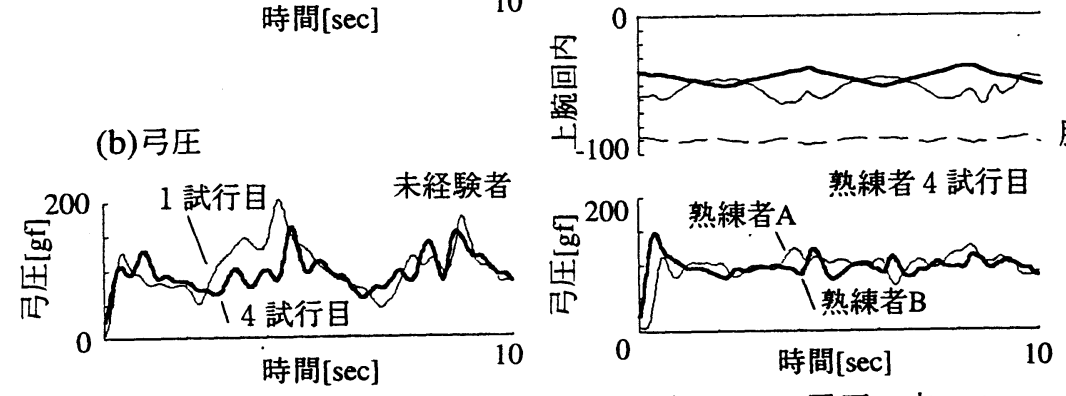

図 2 未経験者と熟練者の運弓動作の比較（タスク：弓圧一定\&Slow，それぞれ 4 試行目で比較）

\section{2-2. 実験方法}

計測用チェロを用い, 熟練者（チェロ演奏 歴 6 年) と末経験者各 2 名について(1)弓圧一 定 (100gf)，(2)弓速一定（200mm/s）の $2 つ$ の条件で20sec間, 各 4 試行弾かせた。弓圧一 定をタスクとする時の運弓動作のリズムはメ トロノームによって与え, 運弓の周期を 3 段 階（Fast:1sec, Normal:2sec, Slow:4sec）に分け て弾かせた。

\section{3. 実験結果および考察}

\section{3-1.熟練者と末経験者の比較}

図 2 に示すように，未経験者はどの関節角 度も比較的小さく，三角波的に変化させてい るのに対し, 熟練者は前腕回内角度と肩関節 外転角度の変化が大きく, 特に弓元での切り 返し時に大きく動いていることがわかる。こ れは熟練者が力制御の容易な弓元では前腕の 回内を利用して比較的速く運動制御を行い, 力制御が困難な弓先の操作時は, 前腕の回内 を戻すことによって手関節を柔軟に動かせる ようにして，ゆっくりと運弓を行うためであ ると考えられる。しかし未経験者は前腕の回 旋と手関節を協調させて制御することができ
ず，弓を引きつけるにつれ弓圧が小さくなっ ている。運動周期の早いNormal,Fastにおいて も, 強くは表れないものの同様の傾向が観察 された。

\section{3-2.運動の経時变化}

図 2 (b)の未経験者の弓圧経時変化より, 運 弓動作は試行回数とともに習熟していること がわかる。しかし 1 試行目と 4 試行目では関 節角度パターンにはほとんど変化が見られな かった。これは本研究では計測しなかった手 関節および指の運動にも変化が表れているた めと推察される。

\section{4.おわりに}

熟練者の関節運動は, 前腕を回内するなど 未経験者と大きく異なることがわかった。今 後は筋骨格モデルを用いた生体内力推定を行 い,さらに身体構造に注目した習熟の要因を 探る予定である。

\section{参考文献}

1)渋谷恒司, 菅野重樹, 加藤一郎：バイオリ ン右腕ボーイング動作におけるスキルの分析, 人間工学, 30(6), 395-403,1994. 